\title{
A SHORT REVIEW OF DOCTORAL THESES ON THE NETHERLANDS-INDIES ACCEPTED AT THE FACULTY OF LAW OF LEIDEN UNIVERSITY IN THE PERIOD 1850-1940'
}

\author{
S. Pompe
}

\section{Introduction}

The study of colonial legal literature has generally been neglected in the postcolonial period in Indonesia. Various reasons underlie this neglect, the main one probably being the view that, since colonialism evidently is a bad thing, the same goes for the law through which the colonial state effected its policies. Other reasons are that it is generally felt to be discriminatory, foreign, and progressively out of step with the modern needs of the country. Furthermore, the role of the Dutch language rapidly declined, notably after 1959, and the younger generation of jurists began to lose Dutch. Since then, pressure in the Indonesian political elite to break with the colonial legal system has been consistent and strong. It is understandable that in this climate the role of colonial legal literature progressively declined.

It is now apparent that a radical break with the legal past as envisaged by the Indonesian political elite has not been achieved. The enormity of such an undertaking and the expertise required to achieve it have generally frustrated a wholesale revision of the legal system. Furthermore, the legal profession showed a pronounced lack of enthusiasm for radical change in repeated instances. As a result in Indonesia, as in many other newly independent nations, the formal legal system can in large part be seen as a continuation of the colonial legal system, even if at present it evidently follows an independent course.

In view of this continuity and the subtle ways in which colonial law has helped shape the modern Indonesian state, as well as for simple reasons of utility and efficiency, there is reason to pay closer and more balanced attention to colonial law and legal literature. There

${ }^{1}$ I am grateful to Professor D. S. Lev and Dr. J. M. Otto who made many useful comments on an earlier draft of this paper. Most of the data for this research were collected by two of our students, Ms. Ch. Coolen and Ms. L. Zeldenrust. They were supervised by our librarian Mrs. C. de Waaij-Vosters. 
has been a continuity not only in the legal system but also in the problems that face the legislator in the archipelago, and conceivably in the considerations underlying their solution. In this perspective legal research should be given added attention.

Such considerations have contributed to a careful re-appreciation of Dutch law by Indonesian politicians in recent years, best exemplified by the large-scale agreement regarding legal cooperation concluded between the Dutch and Indonesian governments in 1985. In the second half of the first five-year span of the program, the first steps were taken along the difficult and sensitive road leading to a critical but constructive appraisal of the use of colonial sources for modern legal development in Indonesia. ${ }^{2}$

One of the results of this program has been a compilation of all doctoral theses on the Netherlands-Indies accepted at the Leiden Faculty of Law. ${ }^{3}$ These theses have been microfilmed and distributed amongst Indonesian state universities, government offices, the Supreme Court, and the Office of the Public Prosecutor.

The importance of Leiden University to the development of the law in the NetherlandsIndies is generally known and hardly needs elaboration. ${ }^{4}$ Suffice it here to point out a number of factors. From 1864 onwards colonial officers were educated in Leiden, first at a separate institution (Rijksinstelling), but from 1876 at the university. Leiden University became the sole institute of education for senior colonial officers until the establishment of a comparable course at Utrecht in the early 1920s: By virtue of the number of its graduates and their high positions in the colonial hierarchy, Leiden remained very influential even after that. As will become apparent in this paper, under the influence of some remarkable scholars, the Leiden Faculty of Law strongly advocated limiting the expansion of Western law and acknowledging adat law. For this reason, the colonial education in Leiden was occasionally referred to as the "Leiden Adat Law School." Leiden strongly influenced policy makers in The Hague and Batavia and attempts to expand the application of the European codes to the indigenous population were at least partially frustrated as a result. ${ }^{5}$

This essay proposes to give a brief review of the collection of doctoral theses on the Netherlands-Indies accepted at the Faculty of Law of Leiden University in the period 18501940. It does not purport to make an in depth analysis of all theses accepted in this period. Theses have been separated into four time spans based essentially on the tenures of Van der Lith and Van Vollenhoven of the chair in the law in the Netherlands-Indies. The essay also tries to place doctoral research in its setting, by looking notably at the university environment, the students and their careers, and at the professors supervising research. A list of the theses can be found in the appendix.

\footnotetext{
2 The rejection of Dutch development aid by the Indonesian government in April 1992 has led to suspension of the program but has not in any way affected the relevance of Dutch and Dutch colonial law in the eyes of many members of the Indonesian legal profession.

3 These were compiled at the request of the Indonesian counterpart and through the intervention in the Netherlands of the legal historian Professor De Smidt. The set had been collected by some students and the library staff at the institute with considerable effort, the university having only established a central register of dissertations in the 1920s. Another result of the cooperation program with specific regard to the law of the Netherlands-Indies has been the bibliography to the colonial legal journal by $\mathrm{H}$. van Katwijk and A. Dekker, Nederlands-Indische rechtsliteratuur. Register op de verhandelingen in het Indische Tijdschrift van het Recht (1849-1950) en de Mededelingen van het Documentatiebureau voor Overzees Recht (1950-1958) (Leiden: KITLV Uitgeverij, 1992).

4 See for greater detail J.M. Otto \& S. Pompe, "The Legal Oriental Connection," in Leiden Oriental Connections, ed. W. Otterspeer (Leiden: Brill, 1989).

5 In fact, the Utrecht education was set up to combat what was regarded as the one-sided approach of Leiden. P. Burns, "The Leiden-Utrecht Conflict: A History of Two Schools" (Unpublished paper, 1984).
} 


\section{The Institution}

In the period from 1850 until 1940, the Faculty of Law of Leiden University accepted 147 doctoral theses on the Netherlands-Indies. ${ }^{6}$ Doctoral research shows a gradual intensification through the years. Whereas in the period 1850-1880 only seventeen theses in this field were accepted, in the following twenty years (until 1900) this number had already doubled to thirty-three theses. In the next period which coincides with the professorate of $C$. van Vollenhoven (1901-1933), eighty-one theses were completed. In the remaining seven years until World War II production stabilized with eighteen theses being accepted.

A number of factors within the academic world played a role in this development of doctoral research, of which three can be mentioned here.

The first factor is the important role the academic infrastructure played in stimulating research in this field. The turning point in this respect, no doubt, was the institution of the chair on law in the Netherlands East-Indies in $1876 .^{7}$ This not only allowed at least one person to devote himself entirely to the study of laws in the colony, but entitled him also to supervise doctoral research in this field. Up to that date doctoral research was supervised by professors whose academic speciality and usually interest lay in other fields of law. The influence of the establishment of the chair is indicated by the fact that after 1876 the number of theses greatly increased. 8

The second of the factors stimulating research into the law of the Netherlands-Indies were the professors holding the chair. The sometimes dominating personalities of these professors could play an important role in stimulating students to write a doctoral thesis. This role is illustrated by the number of theses which they supervised: the first holder, P. A. van der Lith, supervised 27 theses and his successor, C. van Vollenhoven, a remarkable $67 .{ }^{9}$ It may be added that the professorial role-fortunately I daresay-was entirely different from that which is prevalent in Leiden nowadays. Students of Van Vollenhoven were said to have had little freedom in choosing their subject of research or, by force of professorial persuasion, in whether they wanted to do research at all: the professor decreed that a student

\footnotetext{
6 A comparison with present doctoral research is difficult. After Indonesian independence, academic interest in that country declined rapidly at Leiden, notably in the Faculty of Law. In addition, the academic criteria for doctoral research have changed with the years as will become apparent later in this essay. Still, it is interesting to note that over the period 1975-1985 the Faculty of Law at Leiden accepted ninety-nine doctoral theses, of which sixteen dealt with foreign non-EEC law. Eight theses looked at a variety of foreign countries, Togo (1975, E. van Rouveroy van Nieuwaal), Soviet Union (1977, G. P. van den Berg), Mexico (1978, W. van Ginneken), Surinam (1980, J. A. Zevenbergen), Czechoslovakia, (1981, Th. J. Vondracek), Ghana (1981, J. E. Goldschmidt), Soviet Union (1982, E. H. de Jong), and New Guinea (1984, P.B.R. de Geus). In addition, eight doctoral theses were accepted on South African law, five being actually written in Afrikaans. As a result of the institution of international sanctions against South Africa, the link to that country was severed in the 1970 s. In view of recent developments, it is expected to be soon restored.

7 The chair was formally devoted to the study of "Constitutional law and the organization of the Crown colonies and overseas territories and also Islamic law and the other legal institutions and customs of the NetherlandsIndies." The rather complicated institutional history of the education for the Dutch colonial civil service has been described by A.A.J. Warmenhoven, "De opleiding van Nederlandse bestuursambtenaren in Indonesië," in Besturen Overzee, ed. S.L. van der Wal (Franeker: T. Wever, 1977). See also Otto \& Pompe, "Oriental Connection." 8 By the same token, the abolition of the chair in the 1970 s led to a serious decline in academic research on the law in the Netherlands-Indies and Indonesia.

${ }^{9}$ Others include the following: Idema and Boeke (each 8 theses), Carpentier Alting and Vissering (each 6), Schrieke (5), Buys (4), André de la Porte and Blom (each 3), Van Boneval Fauré and Goudsmit (each 2), and finally De Bosch, Van Eysinga, Greven, Van der Hoeven and Cock (each 1).
} 
was fit to do doctoral research which to all practical purposes settled the matter-the subject also being provided by the professor.

The third factor can be found in the changing thesis requirements. A first change was a 1895 law in the Netherlands which abolished the obligation for lawyers to complete their studies with a doctoral thesis. ${ }^{10}$ The second change was an alteration in the doctoral research requirements at Leiden University in 1921,11 according to which the number of mandatory conclusions (stellingen) was reduced, and, notably, need for a research topic to be approved by all the professors who had examined the candidate at the master's level was replaced by required approval by the promotor only.

Besides these academic factors, regard must also be paid to the fact that the nature of Dutch involvement in the colony had become increasingly intense through the years, requiring ever greater numbers of skilled personnel. Furthermore, as the involvement grew, so did the number of job seekers in the Netherlands to whom the prospect of a career in the Netherlands-Indies, and notably in the colonial civil service, became less remote. It did, of course, help in this context that students were candidate civil servants and, as a result, did not have to pay study fees. Completion of a thesis gave a student an edge in career prospects, as will become apparent later in this essay. ${ }^{12}$

All this helps explain why the number of theses increased considerably around the turn of the century, even though the thesis requirement was dropped in 1895 . However, one can only talk about an increase in absolute terms; in relative terms and with the growing student population, the number of doctoral theses completed actually dropped in this period.

As far as the quality of doctoral research is concerned there was a notable improvement at the beginning of the twentieth century. This is not to say that the theses of the nineteenth century are not worth consulting. On the contrary: Van Delden's thesis (1894) constitutes a very early criticism of the labor legislation in the colony, with too many rights being given to the employer. ${ }^{13}$ C.B. Nederburgh's 1880 thesis laid the foundation for the regulation on the Islamic courts, ${ }^{14}$ which constituted the principal law on religious courts in Indonesia until December $1989 . .^{15}$ It was also the period in which persons, who for various reasons were later to become well-known, such as Van Deventer, wrote their theses. Yet the theses that are still widely recognized as classics were written in the twentieth century, notably in

${ }^{10}$ J.K.W. Quarles van Ufford, "Academische proefschriften over koloniale onderwerpen," Bijdragen tot de Taal-, Land-en Volkenkunde van Nederlandsch-Indië 6 (1898): 309.

11 Jaarboek van de Juridische Faculteit 1921-1922.

12 Quarles van Ufford, Academische verhandelingen, pp. 309-10 claims that this is one of the more important reasons for the increase in the number of doctoral theses even after the mandatory writing of such a thesis as an integral part of one's law study had been abolished in 1895.

13 Van Delden was a close friend of J. Van den Brand, whose booklet De millioenen uit Deli (Amsterdam: Höveker \& Wormser, 1902) constituted an important protest against the excesses of private enterprises in North Sumatra at the turn of the century (J. Breman, Koelies, planters en koloniale politiek: Het arbeidsregime op de

grootlandbouwondernemingen aan Sumatra's Oostkust in het begin van de twintigste eeuw (Dordrecht: Foris, 1987). It is possible that when Van den Brand refers to the "learned publications that are only absorbed by a few" (Van den Brand, De millioenen, p. 14) he is referring to Van Delden's early scholarly protest against the penal sanction in labor contracts. See also Otto \& Pompe, "Oriental Connection," p. 236.

14 Priesterraden op Java en Madoera (S.1882-152 jo.153).

${ }^{15}$ A further indication of the influence of Leiden is the criticism by Snouck Hurgronje of Nederburgh's views. This criticism was directed essentially against the view of the penghulu as "priests" who were in charge of courts. By pointing out that they were neither, Snouck advanced understanding of Islam. See generally: D. S. Lev, "Islamic Courts in Indonesia" (Berkeley: University of California Press, 1972). 
the field of adat law. Examples are the studies of V.E. Korn (1924) on Bali and J. Mallinckrodt (1928) on Borneo (Kalimantan) that are both monumental in quality and in size, being 562 and 820 pages long respectively. And indeed, however dubious size is as a criterion of academic worth, it may be regarded as indicative that practically all theses written in the nineteenth century are less than seventy pages in length, with the minute 24-page doctoral thesis by C.J. Schüssler (1892) being the record holder for brevity.

The change in 1895 had important consequences for students interested in doctoral research. They now had two options.

First was to write a thesis immediately after completing law study. A fair number of students followed this course and consequentially not a few theses were written within a short time after graduation, or even sometimes during one's study. The first Indonesian research student to receive his master's degree at the Leiden University Law Faculty (Gondokoesoemo, 1922) obtained his doctorate only twenty days after his graduation. ${ }^{16}$ The second option was to go to the colony immediately after having completed law studies and return to Leiden after having spent some time in the colonial civil service to write a thesis with the added benefit of local knowledge and first-hand experience from the field.

In the latter case the choice of research topic was undoubtedly to some extent determined by whether the student already had some experience in the colonial civil service. Theses written immediately after study were generally more directed toward the study of technical legal problems. It was on the whole impossible to write a thesis on adat law without the benefit of first-hand experience in the Indies, many of the theses in this field being written by persons who had returned from the colony after some years there, as was the case with Korn and Mallinckrodt.

It is going too far to conclude that there were differences in the respective quality of both approaches, though the maturity of students must presumably have had a beneficial effect on the quality of doctoral research of those returning from the field. And when in his private correspondence Van Vollenhoven describes one of his doctoral students as a good-fornothing student, it is to some extent indicative maybe that poor A.J.H.L. Adam was writing his thesis immediately after completing his studies. This professorial comment also makes clear that doctoral research in those years did not necessarily constitute evidence of academic prowess as it generally does nowadays.

\section{The Students}

Whatever the views of the professors regarding the doctoral research of their students, there is some indication that the society outside academia considered a doctoral dissertation as an indication that the candidate must be an achiever. This is evidenced by the fact that

16 Gondokoesoemo's doctoral thesis incidentally was well-received as testified by Van Vollenhoven.

"Two weeks ago our first rechtsschool-Javanese (Gondo) had his promotion (. . .). His book is very good with everything thought out by himself. As a surprise he came with both his panakawans to the promotion with headdresses, sarong, no shoes, one of his paranimfen [ceremonial supporters] even wore a kris. I had expected ten Javanese friends (. . .) instead the place was filled to overflowing, about fifty to sixty people I should say; girls, ladies, all kinds of students, some controleurs studying here, Mr. Abendanon, etc. (. ..) It was quite an event. After the promotion Snouck as rector said a few words about this first promotion."

Personal letter of Van Vollenhoven cited in De Beaufort, Cornelis van Vollenhoven 1874-1933 (Haarlem: Tjeenk Willink, 1954) p. 180; see also Otto \& Pompe, Oriental Connections, p. 244. 
most of the Leiden doctors, though by no means all of them, had an impressive career after completing their doctoral theses, ending generally among the higher echelons of whatever service they had chosen. To give some indication, fifteen eventually became professors, twelve ended up as judges at the colonial Supreme Court, eleven as colonial officers reached the rank of resident or governor, seven became director of justice within the colony (a rank which for all practical purposes could be equated with minister of justice). A fair number of doctoral students became figures of historical importance and reknown, such as Van Deventer, Kusumah Atmadja, Logemann, Van Roijen, Soumokil, and Supomo.

It lies outside the scope of this essay to review all individual careers of the students who completed their doctoral dissertation at the Leiden Faculty of Law. But one or two comments and illustrative stories can be related here.

First, the large majority that entered the colonial civil service remained there. These officers have a few common characteristics: first, they had a relatively long career in the service; second, they were generally posted to several places in the archipelago; third, the distinction between the executive and judicial branches of government was not always clearly drawn, even though there appears to have been a tendency for an official to stick with the branch of government in which he had started out.

Regarding those that entered the government branch, C.G.H. de Jong (1933) is an example of the above-mentioned characteristics. He was first posted as a lowly clerk in Kediri in 1915 and moved to several places whilst working his way up within the colonial hierarchy. In 1928 he was appointed an assistent-resident in East Java. After completing his doctoral thesis he was appointed to the Pasuruan district in 1933 and was finally elevated to full resident assisting the Governor of Central Java in 1935. Another example is B. J. Haga (1924) who was first posted to Sumatra's East Coast district (the Medan area) in a low-ranking post in 1913. After completing his doctoral dissertation he was called to Batavia in 1926, thereupon being nominated governor of the Moluccas and finally, in 1938, of Borneo. Both cases, notably the second, are indicative of the fact that a doctoral thesis did not necessarily precede a colonial career but could be an integral part of it: the career appears to have improved after the doctorate was awarded: in both cases the rank of resident or governor followed within a few years of obtaining the doctorate.

Those graduates who occupied themselves more directly with the law tended to stay with it, though in interchanging capacities. Thus, taking I. A. Nederburgh (1882) as an example, immediately after completing his doctoral dissertation he started his colonial career as a substitute-registrar at the court for indigenous affairs at Meester Cornelis (now Jatinegara in Jakarta). Early in 1884 he was moved to Bantam with the same function, being transferred later the same year to Magelang. In 1885 he was appointed a full registrar for the indigenous courts in the South Celebes district. In 1888 he changed to the executive branch within the judiciary proper to become an assistant public prosecutor, by the end of that same year coming back to the judiciary when he was nominated to the court for Europeans (Raad van Justitie). One year later, in 1889, he was appointed president to all district courts for indigenous affairs in South Celebes, two years later being moved to the Bandung area in West Java in the same capacity. In 1894 he went on furlough to the Netherlands, returning the next year to be appointed judge in Batavia in 1895, registrar at the colonial Supreme Court, and finally judge of that same court in 1903. In 1914 he served for some time as the director of justice only to be appointed as President of the colonial Supreme Court within the same year. It cannot be said that Nederburgh was entirely oblivious to the affairs of the 
colonial state before taking up this last assignment. ${ }^{17}$ Several careers of other legal experts in the colony show the same pattern of constant movement and changes of function. ${ }^{18}$

Kusumah Atmadja (1922) is one of the figures who did not remain solely in the legal world, though he never completely left it either. After completing his doctoral thesis he first became an assistant-registrar at the court for Europeans at Batavia (1923). In 1926 he was appointed a judge for indigenous affairs, three years afterwards being transferred to become a judge at the court for Europeans. This last step was spectacular in the Dutch colonial context. In 1931 he decided to enter local politics and hence combined his judicial function with membership of the city council of Padang. In 1940 he was transferred to the court for Europeans at Semarang. As is now generally known, he eventually became President of the Supreme Court after independence. ${ }^{19}$

As far as academic careers are concerned, Leiden doctors such as Jonker (1882), Th. W. Juynboll (1893), J. J. Schrieke (1909), Boeke (1910), Ter Haar (1915), Logemann (1923), Korn (1924), Soepomo (1927), L.G.M. Jaquet (1925) and Burger (1939) all became professors of great distinction, some at Leiden and others at the Academy in Batavia. All of these had incidentally done their "field-work" in the Netherlands-Indies as civil servants.

Juynboll, evidently more interested in Islamic culture than in Western or Indonesian customary law, was for a time appointed as registrar of the court for indigenous affairs (landraad) in Malang. This evidently was not to his liking: shortly after this appointment in 1896, Juynboll handed in his resignation and applied for a job at the mixed courts for Europeans that existed at that time in Egypt. But before that initiative bore fruit, he was appointed professor of Islamic Studies at Leiden. ${ }^{20}$

Jonker had an even more exotic career from a professional perspective. In keeping with a tradition prevalent in the Netherlands, he never did anything with the law after completing his thesis. Continuing instead with a doctorate in the Javanese language (completed in 1885), Jonker was attached as a language specialist to the colonial authorities in Makassar (now Ujung Pandang) and later of Kupang on the island of Timor. He fell ill in 1901 and

17 That I. A. Nederburgh was not entirely ignorant of the colonial state of affairs (and probably of mind) is not due merely to his academic record and his achievements as a civil servant. He had a long colonial family tradition. His great-grandfather, who incidentally was also the ancestor of another Leiden doctoral student $C$. B. Nederburgh (1880), was S. C. Nederburgh who had been appointed commissionary-general of the VOC in 1790, as such having ultimate control over all colonial territories. S.C. was instructed to bring about the necessary reforms to stave off the worst for the company and at the same time prepare it for transition. After the liquidation of the VOC, he held several important functions in the Netherlands which had a bearing on the Netherlands-Indies and was the main architect of the liberal "Nederburgh report" of 1803, together with D. van Hogendorp. His grandson, S.C.H. Nederburgh, ended his career in the Raad van Indië, which at that time together with the Governor-General constituted the colonial government. Together with C. de Waal (another family name which often recurs in the annals of colonial law) he set up the Bijblad op het Staatsblad van Nederlands-Indië in 1856 (the addendum on the State Gazette), which is the precursor to the present Tambahan Lembaran Negara.

18 One such example is W. A. Engelbrecht (1862), a one-time President of the colonial Supreme Court and director of justice. The compilation of statutes applicable in Indonesia, the last updated print of which was brought out in 1989 with the help of the Dutch Program of Legal Cooperation with Indonesia, is still called the Engelbrecht after its original compiler.

${ }^{19}$ His son presently is one of its Vice-Presidents.

${ }^{20} \mathrm{Th}$. W. Juynboll became famous for his publication on shafi' ite law in the archipelago (Handleiding tot de kennis van de Mohammedaanse Wet volgens de leer van de Shafi' it ische School [Leiden: Brill, 1925]), which is generally regarded as one of the standard books on the subject. The author was helped by his background: both his father and grandfather were professors in Islamic Studies. 
after repatriating to the Netherlands to recuperate, he was appointed a professor in Javanese at Leiden in 1908.

The road followed by the law professors, even those who combined their professorates with a political career, such as notably Logemann and Supomo, was on the whole more straightforward. Ter Haar, for instance, obtained his doctorate in 1915 and was subsequently appointed as registrar at various courts for indigenous affairs in the colony. This experience evidently stimulated his academic interests in the direction of adat law. He remained attached to the colonial civil service with the special task of further study of this law, and in 1934 was appointed a professor at the Academy in Batavia. ${ }^{21}$

Success, of course, remains a relative thing depending on how one measures it and determined as much by one's personal qualities as on the circumstances of coincidence. In view of both the obstacles that had to be overcome and the results to which their research and subsequent careers led them, there can be little doubt that among the Leiden doctors of Indonesian extraction quite a few if not all were outstanding scholars. Whereas even in colonial times some received credit for their achievements, with Soepomo being appointed as professor at the Batavia Academy for instance, the colonial system evidently did not constitute an environment favoring Indonesian success. Yet even so and even within so restrictive a system, recognition of the outstanding capacities of a number of Indonesian Leiden scholars could not be denied. Within the colonial system based on racial differentiation, it is not surprising that all but two Indonesian doctors commenced their post-doctoral careers in the courts for indigenous affairs, these being Gondokoesoemo (1922), Enda Boemi (1925), Kusumah Atmadja (1922), Soeripto (1929), Soumokil (1934), and even Soepomo (1927) for a while. They did not all stay in these courts. The career of Soepomo has already been referred to. Soumokil entered politics and eventually became involved in the ill-fated South Moluccan RMS revolt against Indonesian central authority in the aftermath of which he was executed. Kusumah Atmadja was the first to break the color barrier in the judiciary by being appointed as a judge at the Court for Europeans (Raad van Justitie) in Padang (1929) and Semarang (1940). Two Indonesian Leiden doctors did not enter the judiciary. Soebroto (1925) went into colonial politics, ending his career as a councillor to the Batavia city council. In Leiden he supported the setting up of an alternative to the anti-Dutch Perhimpunan Indonesia student association. Soekanto (1933) entered the colonial department of education.

The impression that can be gleaned from this brief and necessarily incomplete overview is that a doctorate from Leiden was a help in furthering one's career in the colonial civil service. 22

21 He returned to the Netherlands on furlough for the first time in more than twenty years in 1939, which we now know with the benefit of hindsight to have been a singularly ill-chosen time. He was interned by the Germans in 1940 and died at Buchenwald concentration camp in 1941.

22 Warmenhoven, Nederlandse bestuursambtenaren, p. 40 argues that the easy reintegration of the approximately 400 colonial civil servants in Dutch society after World War II, is at least partially due to their high average standards. He also argues that this might be an explanation for a relatively large proportion of them reaching high positions in the state and in business. 


\section{The Theses ${ }^{23}$}

It may be pointed out by way of an introduction that the various periods into which I have divided this section were dominated by certain political and legal issues in the Netherlands. The theses are marked by these issues and reflect the way in which changing ideas and circumstances in the Netherlands have influenced Indonesia. Two examples may be given here.

The first example is that the $1850-1880$ period referred to hereafter coincides with a time of fierce debate in the Netherlands about the meaning of parliamentary democracy. It may be recalled that ministerial responsibility was introduced in 1848 (Constitutional Amendment 1848), but that the limits of this responsibility and the immunity of the Crown only came to be settled during the subsequent two decades. It is relevant to point out in this context that the limitations to which the power of the King eventually came to be subjected were determined by conflicts about the control which he purported to exercise over territories outside Holland. The Constitution stated that the King administered the NetherlandsIndies (in the wording of the Constitution: "opperbestuur"), and the question consequentially arose whether his minister for colonial affairs could be held politically responsible. Parliament took the view, which prevailed only in the late 1860s, that the King (and his ministers) was but the highest executive organ and that as a consequence, Parliament ultimately was competent to regulate both for the Netherlands in Europe and overseas. ${ }^{24}$

The second example concerns the period at the beginning of the twentieth century and regards the establishment in 1918 of the colonial Parliament, the Volksraad. This Parliament was established after lengthy debates on democratic representation in the Netherlands. There is a tendency in practically all publications to refer to the Volksraad as a toothless and useless institution, not in the least because it constituted a most inadequate representation of Indonesian interests. Indeed, the members were partially appointed by the GovernorGeneral and partially elected. Indonesian membership, both elected and appointed, increased from the initial 39 percent to 50 percent in 1931. The Indonesian electorate was, however, formed essentially by the conservative members of the indigenous civil service (Inlands Bestuur) and was very small. Nevertheless, when viewed from a comparative historical perspective, the institution of the Volksraad more or less reflected prevailing conditions in the Netherlands. Until the introduction of the 1917 Constitution in that country, the right to vote and eligibility to public office were seriously restricted. Thus the constitutional reform of 1848 gave less than 3 percent of the population in the Netherlands the right to vote, with less than 1 percent being eligible. The Electoral Law of 1896 increased the proportion of persons with the right to vote to slightly less than 10 percent of the adult male population. Only when the district system was abolished with the Constitution of 1917 did the proportion of persons with the right to vote rise over 20 percent. Women's suffrage was introduced in 1922.25

\footnotetext{
23 A list of publications on colonial law at the end of the nineteenth century can be found in Quarles van Ufford, "Academische verhandelingen over koloniale onderwerpen," Bijdragen tot de Taal-, Land-en Volkenkunde van Nederlandsch-Indië 4 (1880): 482-511 and Quarles van Ufford, Academische proefschriften.

24 T. Koopmans, Compendium voor het Staatsrecht (Deventer: Kluwer, 1983), p. 90 and J.H.A. Logemann, "Collegeaantekeningen over het staatsrecht van Nederlands-Indië," IV (Leiden: mimeo, 1947), p. 94 and the colonial Constitution Indische Staatsregeling artt. 1, 2, 89, 90, and 104.

25 H. Knippenberg and B. de Pater, De eenwording van Nederland (Nijmegen: SUN, 1990 ), pp. 146-50.
} 


\section{0-1880}

As has been established, this period was dominated by the debates on the constitutional developments in the Netherlands. Furthermore, the beginning of the nineteenth century was marked by a series of important legal developments in the Netherlands-Indies itself. The most important of these are the restoration of Dutch colonial power subsequent to the British Interregnum, the administrative consequences of the Cultivation System (Cultuurstelsel), notably the incorporation of the indigenous civil service into the colonial apparatus, and finally, the introduction of codification in the colony. ${ }^{26}$ The theses give expression to these developments in several ways.

\section{(i) Constitutional Law}

The rearrangement of the legal relationship between the motherland and the colony as a result of the reappraisal of the position of the King in the Dutch constitutional system appears to have been the first focus of interest of doctoral research in this period. D. A. Pekelharing (1876), C. Th. van Deventer (1879), and W. A. Engelbrecht (1862) studied issues closely related to this development, such as the legislative competence of the Dutch parliament for the colony, the applicability of Dutch constitutional provisions to the colony and problems of Dutch nationality.

Dealing more specifically with issues of colonial law are the theses of J. H. Toewater (1862) and J. C. Reijnst (1878), which are studies of the judicial organization of the colony. They deal amongst others with the fundamental problem, still relevant today in Indonesia as in many other countries, as to the way in which the independent status of the judiciary is threatened by the fact that judges are, administratively speaking, civil servants. J. J. Momma (1870) looked at certain provisions of the colonial constitution relating to the supervisory authority of the Governor-General on government crops (cultures). ${ }^{27}$

The codes other than the constitution received less attention. T. van Eibergen Santhagens (1859) made a comparative study of colonial and Dutch codes on criminal procedure, whereas Semler (1860) engaged in a similar comparative study in the field of civil law, in particular property rights.

Finally, a very early study was written on formal aspects of the important Agrarian Act of 1870 by W. van Assen (1872).

(ii) the British Interregnum, restoration of Dutch colonial rule, and accommodation of indigenous law

The restoration of the Dutch colonial administration after the British Interregnum (18111816 ) is a second focus of attention. Academic interest appears to have been largely directed towards two aspects of this process: first, the historical development in this period and

\footnotetext{
26 Regarding codification the following examples can be mentioned. In 1847 were enacted the Regulation on the Judicial Organization and Judicial Policy in the Netherlands-Indies (Reglement op de Rechterlijke Organisatie en het Beleid der Justitie in Nederlands-Indië), the General Provisions on Legislation (Algemene Bepalingen van Wetgeving), the Civil Code for the Netherlands-Indies (Burgerlijk Wetboek voor Nederlands-Indië), the Commercial Code for the Netherlands-Indies (Wetboek van Koophandel voor Nederlands-Indië), the Regulation for Civil Procedure (Reglement op de Burgerlijke Rechtsvordering) and the Regulation on Criminal Procedure (Reglement op de Strafordering). The so-called Revised Indonesian Regulation which provided for the law of procedure in both civil and criminal cases involving Indonesians was introduced in 1848 (Herziene Indonesisch Reglement). The legislation is still wholly or partially in force in Indonesia today.

27 The crucial article was art. 56 of the Regeringsreglement (S.1855-2), which was voided in 1915 (S.1915-491).
} 
second, the consequences of the increased involvement of the colonial administration as a result of policies initiated in this period.

Regarding the first aspect, a combination of four theses give a comprehensive historical review of the transitional period from 1770 until 1819. They concentrate on the colonial period leading up to Daendels (G.J.A. van Berckel [1880]), the reforms of Daendels with particular reference to its consequences for the administration of justice (D. J. Mackay [1861]), the British Interregnum (H. D. Levysohn Norman [1857]) and, finally, the first years of the reestablishment of Dutch colonial authority from 1816 until 1819 (I.H.J. Hoek [1862]).

With reference to the second aspect, attention was primarily directed towards the way the indigenous normative system could be accommodated in the colonial legal system. $\mathrm{H}$. Delden (1862) studied the question of the succession-rights of the indigenous rulers (regenten) who were essential in the colonial system of indirect rule. H.L.E. de Waal (1880) made a general study of the influence of colonial law on the indigenous normative systems. The thesis of C.B. Nederburgh (1880) deals with the administration of justice for Muslims in the Netherlands-Indies, which has already been mentioned.

\section{1-1900}

This period clearly shows a greater diversity in academic interest as evidenced by the doctoral theses. There is a marked diversification away from constitutional law and colonial administration research topics that so evidently dominated the previous decades. Relatively speaking most theses still deal with the subjects of constitutional law and administration. But by the 1880s, the important issues that earlier dominated research in this field have been replaced by new points of interest and, arguably, an entirely new approach.

One of the most remarkable new developments in doctoral research in this period is the interest in indigenous legal systems in the archipelago. It may be that this interest is at least partially motivated by the desire to bring about a more effective government, rather than by some scholarly exercise to improve knowledge about indigenous legal systems. Indigenous laws are dealt with by necessity, inasmuch as relevant to the colonial government and by and large considered from a colonial perspective. ${ }^{28}$

However that may be, many theses written in this period contain valuable information on indigenous laws in Indonesia, and the first tentative steps in the systematic study of these laws are taken in this period.

(i) Constitutional Law

Looking first at constitutional law, there is an evident shift of interest away from constitutional relations in the Netherlands and their effect on the colony, to the constitutional affairs within the colony itself.

Most theses concentrate, in fact, on the nature of the relationship between the colonial government and the indigenous authorities in the various regions of the colony. Thus, H.K.J. van Deinse (1887) considers the Royal Districts (Vorstenlanden) of Central Java. These

28 The increased interest and involvement of the European powers in the colony is connected to the rapid increase of the European population group in there. This was furthered in turn by the lifting of immigration restrictions in 1870 when the Agrarisch Besluit opened the Netherlands-Indies to private entrepreneurs. In 1812 the European population group numbered 4,000. After 1870, it increased rapidly, reaching 76,000 in 1900. J. G. Taylor, The Social World of Batavia. European and Eurasian in Dutch Asia (Madison: The University of Wisconsin Press, 1983), p. 128. 
districts were semi-autonomous and therefore had maintained a certain degree of freedom of action in government and the administration of justice. This thesis considers the main elements of this autonomy inasmuch as they are relevant to the colonial state (such as succession rules) but pays little attention to the way the indigenous legal system actually functions in practice. As such, the thesis is not so much a study of the nature of indigenous authority, as the title seems to indicate, but rather of the formal limits of colonial authority. H. Massink's (1888) thesis follows much the same approach with respect to Madura and H. C. van Meerten's (1887) with respect to the Priangan.

In more general terms, an identical approach is followed by R. H. Kleijn (1889) giving a general overview of colonial administration before and after the introduction of the colonial "constitution" (Regeringsreglement) in 1854 and by F. E. Couperus (1882) who looks at West Sumatra. A.C.N. Pieren (1884) studied the various duties of the indigenous population to the indigenous rulers according to indigenous law (the so-called pantjen-diensten). This study concentrates on the most adequate methods through which these duties should be suppressed for being oppressive on the Indonesian subjects. ${ }^{29} \mathrm{P}$. H. de Clerq (1881) looked at the position of the indigenous rulers within the constitutional framework of the colony with particular attention to their immunity from persecution.

Besides studying local government, the theses in the field of constitutional law deal with a variety of subjects. G. D. Gockinga (1884) wrote a thesis on the applicability of certain provisions of the Dutch Constitution to the colony. J. H. Meiss (1883) considered the history of the colonial administration before the reforms introduced by the 1854 colonial "constitution." G. D. Willinck (1889) studied legal aspects of colonial coinage. Th. Thomas (1893) looked at quasi-taxation in the colony. Finally, G. W. Uhlenbeck (1887) concentrated on the legal relationship between the colonial state and the Christian churches.

\section{(ii) Agrarian Law}

One remarkable feature of most above-mentioned theses is that they often also consider indigenous rights on land. The inclusion of agrarian law in constitutional law theses can be explained by the fact not only that land was, of course, of prime importance to the commercial interests of the colonial state, but also that the rights to land touched upon the very legitimacy of the colonial state itself.

The last question in particular dominates doctoral research in the field of agrarian law in this period. Theses in this field can be split up into three groups, one of which concentrates on the issue as to whether land is in principle state property (staatsdomein), the second the nature of indigenous rights to land, and third whether these rights should receive recognition in colonial law. ${ }^{30}$ These issues are not fully resolved to the present day.

\footnotetext{
${ }^{29}$ The author suggests that these duties should be suppressed by increasing the remuneration paid to the rulers (traktementen), making them less dependent on these duties. Also, he recommends an increase in the number of colonial civil servants and in their responsibilities. As has been established notably by H. Sutherland, The Making of a Bureaucratic Elite (Singapore: Heinemann, 1979), the reasons why these pantjen-diensten had become oppressive are closely related to colonial policy at the beginning of the century.

${ }^{30}$ The staatsdomein concept was introduced by Raffles. It was laid down formally in the Agrarian Law of 1870 (S.1870-118). This law provided that, as a rule, all land was deemed to be state property, including land subject to indigenous rights. There were strong restrictions on the alienation of land subject to indigenous rights to the non-indigenous population, however (Verbod van veroreemding van erfelijk individueel gebruiksrecht S.1875-179). Nevertheless, land subject to such rights could be leased by the non-indigenous population. Indigenous property rights thus seemed formally secure, even though there were both formal and informal methods of getting around these restrictions. The staatsdomein concept has been much criticized in post-independence Indonesia. It
} 
J. A. Nederburgh (1882) made a study of the staatsdomein concept. He dealt first with the precise juridical meaning of the concept, which is far from self-evident, and second with the property rights over land which is state property. In this respect he tried to balance the rights of the indigenous population with those of the commercial interests. H. C. Pennink (1885) dealt with Western private rights to land, in particular before 1870, whereas J. Barlagen Bussemaker (1887) concentrated on indigenous rights to land. This thesis focuses on the old stumbling block of the nature of indigenous rights to virgin land and the formalities that must be fulfilled according to these laws for occupation of such land to be valid. The complicated relationship between communal and individual rights to land are considered, the author concluding very much in the spirit of that period-and not unlike the spirit of the present day - that conversion of indigenous rights to rights in the Dutch Civil Code offers the best solution.

\section{(iii) Criminal Law}

Regarding the ongoing codification, one of the most important developments in the latter half of the nineteenth century undoubtedly was the introduction in 1872 of the Criminal Code and the Code of Criminal Procedure for Indonesians. ${ }^{31}$ This development resulted in a marked increase of doctoral research in the field of criminal law in this period, which emphasized the application of both formal and material criminal law for Indonesians by the landraad-courts.

Two theses provided general introductions to procedural law, with W.A.J. Davelaar (1884) comparing the law of criminal procedure regarding crimes (i.e. not delicts) for Indonesians with the law applicable for the non-indigenous population, and A.J.C.E. Heijcop ten Ham (1888) giving a general review of both civil and criminal procedural law applicable to Indonesians in this period. More specific aspects of procedural law were studied by $H$. $P$. Grobbee (1884), who looked at the role of the Muslim religious adviser, generally called the penghulu, in criminal cases before the landraad-courts in cases involving Muslims. Grobee claims that at that time pesantren-education, the $\mathrm{Haj}$, and the haji-examination did not guarantee that the penghulu would be sufficiently knowledgeable in Muslim law to be of use to the court.

With regard to material criminal law, two studies looked at general issues of criminal law, H. J. Matthes (1887) studying the legal safeguards against capital punishment in the colony, and N. Dirkzwager (1892) considering the draft of the new Criminal Code in the light of its possible effect on the Indonesian population of the archipelago. Finally, J.C.G. Jonker (1882) made a study of Javanese law which at times had to be applied by the courts, based on his extensive knowledge of Javanese literary sources, as evidenced by his later doctorate in Arts. His thesis consists of an analysis of the criminal provisions in Javanese codes Nawolo Pradoto, Angger Sedoso, Angger Agung, and Angger Gunung, and constitutes a serious attempt to free research in indigenous laws from the conceptual framework imposed by the Western legal discipline. The author points out repeatedly that Javanese law is very different from Western laws and refrains from a systematic comparison of crime and

appears however, that the concept is continued in the Basic Agrarian Law of 1960 (nr. 5/1960), art. 2(1) stating that all land is state property. Research indicates that indigenous rights on land are very much alive today and that their status is as uncertain as it was a century ago. M. B. Hooker, Adat Law in Modern Indonesia (Kuala Lumpur: Oxford University Press, 1978), F. von Benda-Beckmann, Property in Social Continuity (The Hague: Nijhoff, 1979), H.M.C. Slaats \& M. K. Portier, Grondenrecht en zijn verwerkelijking in de Karo-Batakse Dorpssamenleving (Nijmegen: K. U. Nijmegen, 1981).

${ }^{31}$ Wetboek van Strafrecht (S.1872-85); Politiereglement voor Inlanders (S.1872-111). 
punishment in the East and the West. Of course, this thesis necessarily has a Western outlook, insofar as Javanese law has no clearly distinct legal category for criminal law as has the West. Furthermore, and more importantly, Jonkers interpreted the law in a manner characteristic of Western jurists. He put great emphasis on written materials interpreted in an analytical manner, thus giving them a meaning quite different from that which Javanese society had traditionally accorded them.

\section{(iv) Other Subjects}

There are a number of theses on more or less isolated subjects.

In the field of civil law and the law on civil procedure, H.J.E. Tendeloo (1895) looked at the law on immovables, C. J. Schüssler (1892) considered injunctions (beslag) in the landraadcourts, and J.H.W.B. Visser (1983) made a comparative study of the the role of the oath in civil procedure according to indigenous, Muslim, Chinese, and Western law.

Regarding the differentiation between population groups, it is in this period that the group of Foreign Orientals (V reemde Oosterlingen) formally acquired separate legal status. ${ }^{32}$ J.W.C. Cordes (1887) and E. Zorab (1890) consider the effect of this provision from a private and a public law view respectively.

Public international law received some attention too, in the form of the theses by J. E. de Sturler (1881) who looked at the treaties between the Netherlands and Spain, and England and Portugal on the colonial boundaries; A. Heijman (1895) who studied the treaties regarding the colonial boundaries on Timor (the Timor-tractaten); and F. G. van Panhuys (1891) who considered deportation of foreign criminals from the colony.

Whilst this period coincides with so-called liberalism in colonial policy, there are only two theses dealing with private enterprises in the colony. C. H. van Delden (1895) made a critical study of labor law with particular reference to the so-called Koelie-ordonnanties, ${ }^{33}$ which provided among other things for labor contracts enforced by penal sanction. A. Lens (1889) looked at the legal status in the colony of societies with a legal personality established in the Netherlands.

Finally, regarding Muslim law, Th.W. Juynboll (1893) wrote a doctoral thesis on security according to the shafi'ite law school.

1901-1933

The first thirty years of the twentieth century which coincided with the tenure of Van Vollenhoven were the most fruitful in terms of academic achievement in the field of colonial law. The number of theses written in this period increased dramatically and there were a much greater variety of subjects. Colonial society grew ever more complex. Furthermore, the "ethical policy" of the Dutch, and by extension colonial, government in the first two

\footnotetext{
32 The Algemene Bepalingen van Wetgeving of 1848 distinguished between Europeans in the colony and indigenous inhabitants. The Regerings-Reglement of 1855 explicitly listed non-indigenous non-European inhabitants (i.e., the Chinese, Arab, and Indian population) in the indigenous inhabitants group, but in practice the Chinese, Arabs, and Indians were treated as distinct groups in their own right in the course of the nineteenth century. The amendment of the Regerings-Reglement of 1920 (art. 109 being amended by art. 163) and later the Indische Staatsregeling of 1925 confirmed this development.

33 The Coolie Act considered here is S.1889-138.
} 
decades of this century also led to an increased involvement of the state apparatus in everybody's daily life. ${ }^{34}$ All this provided ample research material for law students.

The focus of interest in doctoral research in this period appears to have been less directed towards methods of harnessing the power of the colonial state, which by then appeared to be sufficiently firmly rooted, than on the way state power can be exercised effectively and, in some circles, equitably.

The change of policy at the turn of the century, and maybe the change in atmosphere at home and in the colony, is very much evident in the field of constitutional law. Thus, ideas of democratization created the first cracks in the monolithic colonial edifice. At the same time, the awareness grew that an effective and committed government would not be possible without some degree of decentralization. Most theses concentrate on these issues.

The most manifest effect of the developments described above was the establishment of the colonial Parliament, the Volksraad, in 1918. This development has already been referred to. It led to a redistribution of governing competences between the Governor-General, the Volksraad, and the hitherto powerful Raad van Indië which was reduced to an advisory body. Another effect was ongoing administrative reform, which was initiated in 1903 and culminated in the amendment of the colonial constitution in 1925 which largely restructured the colonial administration. ${ }^{35}$ This reform involved an increased delegation of government authority to lower levels of the colonial administration, the creation of people's representation at the regional level (notably in townships), the gradual transfer of government authority to the indigenous civil service the Inlands Bestuur (Ontvoogding), and the attribution of greater autonomy to Indonesian administrative levels such as the desa.

\section{(i) Constitutional and Administrative Law}

On the basis of the theses in this field basically four issues can be discerned. The first issue concerns the effect the constitutional changes, whether projected or effected, had on the regulatory competences of various state organs in the Netherlands and the NetherlandsIndies respectively.

Regarding the Netherlands, a constitutional reform in 1922 led to the debate as to whether the colony's autonomy in regulating its own affairs should be increased. In the face of a rather toothless colonial parliament, such an increase would primarily strengthen the position of the Governor-General. As a result, this debate returned to the issue discussed thirty years before, namely the limits of the regulatory competences of the Crown. In this period, this matter was considered by A.A.J. de Neef (1915), V. D. Krone (1922), and H. J. Wytema (1931).

Furthermore, and in the context of a general study on whether the colony had a legal personality separate from that of the Netherlands, H.W.C. Bordewijk (1905) specifically focused on the meaning of budgetary indivisibility provided for in the Dutch constitution at the time in order to support his contention that there was no such separation. A. Jansen (1932) made a comparative study of the Dutch and colonial parliament in fixing and approving the state budget.

\footnotetext{
${ }^{34}$ One of the important initiators of this policy was Van Deventer, whose doctoral thesis at Leiden University has been mentioned above.

35 Amendment 23 June 1925 (S.1925-415 jo.577). From this date the colonial constitution became know as the Indische Staatsregeling.
} 
Regarding the Netherlands-Indies, two theses looked at various aspects of the newly created relationship between the Governor-General and the colonial Parliament. P.H.C. Jongmans (1921) studied the historical development of the extraordinary rights of the Governor-General, notably with regard to the competences of the Volksraad in this field. This study looks among other things at the banishment of E.F.E. Douwes Dekker, T. Mangoenkoesoemo, H.J.F.M. Sneevliet, and R. M. Soewardi Soerjaningrat. J. J. Schrieke (1909) wrote a thesis and is generally regarded as the "discoverer," if that term is appropriate here, of a legislative instrument that came to be increasingly used during that period by the Crown (Ordonnantie met Koninklijke Medewerking). F.W.T. Hunger Jr. (1928) studied the federal state structure for the colony, a subject which is not without current relevance.

The second issue deals with the way delegated legislative authority at lower levels related to legislative authority at higher levels. B. F. Roskott (1931) gave a general overview of the subject of delegated and central regulating authority. P. F. Woesthof (1904) looked at the regional authorities; H. J. Spit (1911) and Th.H.M. Loze (1929) studied the autonomy of indigenous states at an intermediate level, while Gondokoesoemo (1922) and L. Adam (1924) considered village authority. L. A. de Waal (1911) looked specifically at the delegation of fiscal authority and local taxation.

The third issue concerns the gradual transfer of government authority to the indigenous civil service, the Inlands Bestuur (Ontvoogding). A general theoretical argument in favor of increased devolution of authority to the indigenous states was put forward by B. J. Haga (1924). ${ }^{36}$ The effect of ontvoogding in Java and Madura was the object of the theses by L. Pronk (1929) and J. M. Pieters (1932). J. H. Heslinga (1920) looked at the effect of a number of measures in this field in various regions throughout the archipelago, while the effect of one of the most important reforms (that of 1922) was considered by A.J.W. Brückel (1930).

The fourth issue covers the effect the constitutional changes both within the Netherlands and the colony had on the body of legislation existing at the time. To start with, J. Greup (1906) looked into the applicability of the constitution to the colony (an ever-popular subject), with particular regard to the constitutional amendment of 1887. A.J.H.L. Adam (1905) studied the legal effect of constitutional amendments in the Netherlands on legislative instruments in the colony. Specifically regarding the colony, H. Marcella (1913) looked at the Law on the General Principles of Legislation (Algemene Bepalingen van Wetgeving), which is still partially in force in Indonesia today. He considered in particular their explicit and implicit annullment and judicial review. J.H.C. van der Beeke (1915) looked at legal aspects of publishing laws in the colonial State Gazette (Staatsblad).

Finally, there are a number of theses on a variety of aspects in this field of law.

F. H. Visman (1931) and C.G.E. de Jong (1933) looked at the organization and competences of the colonial police; W. H. Alting von Geusau (1917) and C. Lion Cachet (1933) considered the relation between the colonial state and the Christian churches; W. Brokx (1925) studied the right to live and travel in the colony; T. S. Smit (1928) the government licensing system; J. W. de Klein (1931) the autonomous government in the Priangan from VOC times until the end of the nineteenth century; and P. H. Angenent (1933) the effect of

\footnotetext{
${ }^{36}$ This was the first thesis in which the argument was put forward that the oppressive rule of the indigenous elite was at least partially caused by colonial rule, rather than by some inherent feature of Indonesian society. For an interesting personal note on the administrative practice under Haga when he was governor of the Moluccas, cf. J. van Baal, "Voltooid Verleden," in Van der Wal, ed., Nederlandse bestuursambtenaren, pp. 111-29.
} 
the institution of colonial councils for waterworks in the Royal Districts (Vorstenlanden) in Central Java.

\section{(ii) Adat Law}

As C. van Vollenhoven was chairman of the Faculty throughout these years, it is not surprising that this champion of indigenous laws (adat law) strongly promoted research in this field. In his view, such research was an essential element in his endeavor to understand this law better and thus strengthen its position in the face of encroaching Western law.

The large number of theses on adat law can generally be divided into two categories, namely theses giving a more or less comprehensive documentation of that law in a particular region and theses concentrating on a particular subject (sometimes limited to a particular region).

Looking first at the geographical category, V. E. Korn (1924) wrote a well-known study on Balinese adat law. Besides its impressive size (562 pages plus appendices), this thesis is remarkable in that it constitutes one of the most comprehensive studies of Balinese adat law to date, divided by subject and region. Commonly shared Balinese characteristics are considered too, such as the shared religious traditions, the community organizations in the various Balinese districts (bandjar in Buleleng, Jambrana, and South Bali), indigenous government and the local and intermediate levels, the irrigation communities, administration of justice, family and inheritance laws, agrarian laws, and so on. J. W. de Stoppelaar (1927) wrote an equally comprehensive study on East Java including Madura; J. Mallinckrodt took the same approach in his monumental study of more than 850 pages on the adat laws of Borneo (now Kalimantan); whilst Th. Nieuwenhuizen (1932) followed with his thesis on the Sasak area of Lombok.

Most theses took the second, thematical approach. Interest was generally directed towards family and inheritance law, the law concerning land and water, and to a lesser extent judicial procedure.

Regarding family and inheritance, P.A.F. Blom (1914) made a general study of these laws throughout the archipelago. L. B. van Straten (1927) made a comparable study of dowry in indigenous laws in the Netherlands-Indies, looking at the influence of Islam, Hinduism, and Christianity as well. W. Hoven (1927) bridged both the geographical and thematical categories in that he concentrated on family and inheritance laws in the Palembang region (the Pasemah). S. R. Boomgaard (1926) and E. A. Boerenbeker (1931) looked at the social and legal position of women in indigenous societies throughout the archipelago, the former author concentrating on the position of married women in adat law.

Regarding land and water, W. G. Joustra (1922) looked at water rights throughout the archipelago, concentrating on their relevance for fishing rights and sawah-irrigation. A. Enda Boemi (1925) studied rights to land in the Batak-districts. Soebroto (1925) made a comprehensive study of sawah-leasing throughout the archipelago. J. W. van Royen (1927) looked at adat rights on land and water in the Palembang region, whereas J. R. Lette (1928) did highly original comparative work on land rights in postrevolutionary Russia and (prerevolutionary) Java. Finally, Soekanto (1933) looked into the legal and religious function of crops.

Regarding judicial procedure, the well-known scholar B. Ter Haar Bzn. (1915) made a study of both Western and indigenous judicial procedure, looking notably at various alternatives to actually bringing a case before the court for adjudication. In this context he paid attention among other things to personal actions by the aggrieved against the goods or the 
person of the other party, and to resolving conflicts through consultation or arbitration. K.J.L. Enthoven (1927) made a study of Western case-law concerning adat law.

Finally, there are two theses in this category that stand on their own. Soeripto (1929) made an extensive study of a number of indigenous written codes of Java, whereas H. M. Kits van Heijningen (1916) looked at certain aspects of indigenous penal law.

\section{(iii) Agrarian Law}

Land, and notably land subject to indigenous land rights, remained an issue attracting academic attention in this period, both from a public and a private law perspective.

From a public law perspective, much of the issue of rights of the colonial government and indigenous authorities to land had been settled in the previous century. There were a number of non-indigenous privately owned estates (particuliere landerijen) granted largely as a royal favor at the beginning of the eighteenth century (when the King could still do so). The owners not only had the normal rights and duties under private law, but also had some public law competences such as the maintenance of public order. It was felt that these comprehensive rights could not be preserved under the post-1870 agrarian law. Furthermore, there was a general feeling that public law duties were the exclusive domain of the government. The idea, as a result, was to convert these comprehensive rights of ownership to rights of usufruct in private law, with the government taking over the public law rights and duties. In 1911 (S.1911-38) the first steps were taken on the long road of expropriating these estates.

The debate which this policy stimulated, both before and after it was actually put into effect, attracted considerable academic attention. Thus, the theses of M. de Muinck (1911) and W. J. Beck (1925) look at the expropriation issue, with two other theses considering the bleak future of these particuliere landerijen (E. van Delden 1911) and the governmental authority to convert them into a type of concession (K.H. Korff 1913).

The private law perspective of agrarian law was considered in two theses. S. Jaarsma (1918) concentrated on what evidence regarding indigenous and Western forms of land ownership was acceptable before the courts. B. Ockers (1928) considered the role of land registration in the transfer of Western property rights.

A thesis that stands out on its own is Soepomo's (1927) research on agrarian reform in the Surakarta district. This thesis involves an extensive study of the effect of the colonial legislation on indigenous property rights and as such is as much a study of colonial law as it is of indigenous property rights.

\section{(iv) Commercial Law}

The turn of the century was marked by increased economic activity caused notably by the opening up of the colony to private capital in 1870 . This led to a variety of theses on commercial law generally in this period, which concentrated by and large on four issues.

The first issue, commercial law proper in the sense of the law on commercial ventures, suprisingly enough was the focus of only one thesis, with S. F. Duurvoort (1918) making an inventory and classification of the various types of commercial ventures having legal personality in colonial law.

The second issue relates to labor law. This subject was studied in two theses, with $\mathrm{H}$. G. Heijting (1925) looking at the by then controversial koelie labor legislation for plantation 
workers on Sumatra's east coast, and K. J. Boejinga (1926) making a comprehensive study of the existing labor law at the time.

The third issue covers shipping. J. A. Kok (1931) made a study of the protective measures taken by the Netherlands and the Netherlands-Indies favoring Dutch shipping companies. F.J.H.W. Sandbergen (1931) took a public international law approach in looking at the nationality of ships registered in the Netherlands and in the colony.

The fourth issue relates to taxation. J.H.A. Logemann (1923) studied taxation of private limited companies in the Netherlands-Indies, whereas R.J.W. Reys (1925) looked at income taxation of the indigenous population.

(v) Religion

Three theses were written on subjects related to both law and religion.

Regarding Muslim law, Koesoemah Atmadja (1922) wrote a thesis on Muslim religious foundations and organizations; A. H. van Ophuijsen (1907) looked at the Marriage Law of 1895,37 which provided among other things for Muslim divorces with particular attention to unilateral divorce; 38 and J. Eisenberger (1928) considered the legal aspects of the Haj pilgrimage, looking amongst others at why the colonial government should be involved in the Haj at all, legislation relevant to the pilgrimage, the role of the Dutch consular representation in Jeddah, health aspects, and transport.

Regarding Hindu law in Indonesia, T. C. Lekkerkerker (1918) analyzed formal Hindu law and considered the way it is incorporated in the practice of Balinese customary law.

\section{(vi) Economics}

It has been, and indeed still is, a curiosity of Leiden University that it dispenses with a separate faculty or department of economics. Instead, economics traditionally has been part of the Faculty of Law and theses on economics have been accepted at that faculty.

The period 1901-1930 witnessed the rise of the study of the "Indonesian household" as it has been often called. Three theses can be mentioned here. The first is that by J.H. Boeke (1910), one of the pioneers in this field, whose thesis dealt with the nature of the indigenous economy and the essential pre-conditions for its development. It also looks at the influence of the Western capitalist market economy on indigenous society and at the role of the colonial government in stimulating economic development with greater Indonesian participation. Following a more anthropological rather than theoretical approach, the study by $W$. Huender (1921) was based essentially on an assessment of the effect of capitalist economic production modes and government measures such as taxation on the standard of living for Indonesians. Finally, and concentrating almost exclusively on the Western economy, J. C. van der Stok (1913) looked essentially at the nature of government economic involvement in the colony, both in the field of public services (public works, transport, postal, telephone, and telegraph services) and of economic ventures, notably in the plantation sector (rubber, kina, coffee, sugar).

\footnotetext{
37 Huwelijksordonnantie S.1895-198.

38 Appendix Il contains an interesting example of a conditional unilateral divorce contract ( $t a^{\prime} l i k$ talak) which is often concluded upon marriage between Muslims in Indonesia up to the present day. Similar contracts have recently been drafted by governments in certain Western countries for female nationals marrying Muslims. Following the enactment of the Marriage Law in Indonesia in 1974, in which divorce grounds and procedure appear to be exhaustively regulated, the status of these contracts is unclear even though they continue to be used.
} 
(vii) Other

There is a fairly large number of theses on a variety of other subjects.

Only one thesis in this period deals with civil law proper. This is by J. H. Wagener (1932), who made a comprehensive comparative study of private law in the colony and in the Netherlands, looking among other things at marriage and divorce, property rights, inheritance law, the law of contracts, the law on evidence, commercial law, and bankruptcy.

Two theses deal with the internal conflicts of laws (intergentiel recht) that gradually took shape in the colony in this period. Thus, A. C. Tobi (1927) looked at the voluntary submission procedure of Indonesians and Foreign Orientals to Western colonial law. J.J.W. Klein (1933) made a comprehensive study of the legal interaction of the different population groups in the colony.

A number of theses deal with the judicial system in its widest sense. Regarding judicial organization, A. Mieremet (1919) made an extensive study of the formal constitutional position and nature of the indigenous administration of justice in the colony, whilst J. J. van de Velde (1928) looked at the courts competent in Muslim cases. Regarding the law of procedure, M. van Blerkom (1916) made a study of the 1914 reform of the law of criminal procedure applicable to Indonesians, whilst G. Wijers (1931) looked at the executory force of judgments competent in cases between Indonesians (landraad).

H. Fievez de Malines van Ginkel (1924) wrote a study in public international law on the relations between the colony (as an integral part of the Dutch state) and third party states. J. A. Jonkman (1918) looked at a subject that has little legal content, namely the colonial schooling system for the Indonesian population. This thesis constitutes an argument in behalf of schools run by and for the Indonesian population.

It is interesting to note that, apart from some references to criminal law (also adat criminal law) in a number of theses, no thesis focusing on that subject was accepted at the Faculty in this period. This is surprising, as the Criminal Code was one of the first codes to have been declared applicable to all inhabitants of the archipelago in $1918 .{ }^{39}$

\section{3-1940}

In this period production stabilized at about the same level as the previous period, with an average of 2 theses on law in the Netherlands-Indies being completed every year. The early death of Van Vollenhoven in 1933 clearly did not affect the volume of research in that field which by then was firmly established.

In spite of growing political tensions the colonial state appeared to be ever more secure as well. This is evidenced among other things by the surprising lack of interest amongst doctoral candidates (and their professors) in constitutional law. The focus of attention appears instead to have been directed towards economic subjects: Boeke replaced Van Vollenhoven

\footnotetext{
$39 \mathrm{~S} .1917-497$ art. 1 jo. S.1917-645. It is interesting to note in this context, that this code was translated into "Malay" to make it more accessible to Indonesians. This translation showed that Malay could be perfectly adequate to express complicated technical concepts, something which had hitherto been doubted. I have been told by a prominent legal scholar in Indonesia, that this translation may have been an important stimulus to the Indonesian intelligentsia for promoting "Malay" as the national language of the country, and that as such it was instrumental in the inclusion of the reference to "Bahasa Indonesia" as the national language in the 1928 Youth Pledge.
} 
as the great source of inspiration in this period as research in economic subjects and in law gradually but inevitably drifted apart.

(i) Constitutional and Administrative Law

Only seven theses on constitutional and administrative law were accepted in this period. Two of these deal with the colonial parliament, the Volksraad. I. Samkalden (1938) studied the devolution of authority from the Netherlands to the Netherlands-Indies which was the natural result of the institution of parliamentary institutions. J. Drijvers (1934) looked at the separation of powers within the colony resulting from the institution of the Volksraad.

The other theses in this category cover issues of decentralization. Regarding the indirectly governed territories, G. W. Fris (1940) dealt with the extent to which colonial legislation also applied to territories outside Java. Regarding the colonial administrative structure, M. Brouwer (1936) made a special study of the Minahasa district, looking notably at the effect of the ontvoogding and decentralization measures. W. P. van Dam (1937) looked at the decentralisation reforms of 1931 at lower administrative levels on the islands outside Java and Madura. ${ }^{40}$

Finally, with regard to the administration of justice, H. D. von Meyenfeldt (1936) studied the indigenous administration of justice on the East Coast of Sumatra based essentially on the 1931 reforms, ${ }^{41}$ while $H$. Campen (1939) made a comprehensive review of the administration of justice, both colonial and indigenous, on the islands outside Java and Madura.

\section{(ii) Adat and Criminal Law}

All theses in the field of adat law deal with its criminal law aspects. The Criminal Code having been made applicable to Indonesians in 1918, the major interest in these theses appears to be directed towards the question as to the way in which indigenous criminal law (a problematic point as such) interacted with formal colonial law in this field. Chr.R.S. Soumokil (1934) studied the role of the expert adviser in criminal cases; W. H. Overbeek (1934) considered provisions for the exclusion of liability according to both Western and indigenous criminal law; and N. W. Lesquillier (1934) considered the way crimes are viewed from the perspective of indigenous society and the extent to which such a view is respected in colonial courts.

\section{(iii) Economics}

The largest category of theses in this period consists focus on economic subjects. They can be roughly divided into two categories, the first looking at the external economic relations of the colony and the second concentrating on its internal economic structure.

With respect to external economic relations, A.J.A. Prange (1935) looked at colonial finances which, according to his indications, are based essentially on the fluctuations of the international trade with the colony; and L.G.M. Jaquet (1935) considered the causes of Japanese economic development with particular reference to its effects in the Netherlands-Indies in terms both of formal trade relations and of economic influences.

More theses concentrate on the internal economic structure of the colony. N. D. Ploegsma's (1936) thesis studies the nature of the village economy in Java and Madura, attempting to analyze indigenous economic structures at the local level, excluding inasfar as possible influences from the capital-based economy. Several theses concentrate on the way govern-

\footnotetext{
${ }^{40}$ Hoogere Inlandsche Verbanden Ordonnantie Buitengewesten (S.1931-507).

41 Inheemse rechtspraak in rechtstreeks bestuurd gebied (S.1932-80).
} 
ment cultures (such as sugar, tea, and coffee) influenced indigenous economic structures at a local level. Looking at the money-based economy gradually emerging in indigenous economies at the local level as a result of these cultures, several concentrate on the way the mode of payment of salaries influenced the indigenous economy. J.D.N. Versluys (1936) tried to give a comprehensive review of different forms of payment in the various sectors of the economy, while J. de Ridder (1935) and P. Bakker (1936) studied the effects of the sugar, tea, and coffee-cultures on the indigenous money-based economy. A comprehensive study of the progressive opening up of the interior of Java to the capitalist economy and the effect this has had on the structure of indigenous society was made by D. H. Burger (1939).

Finally, W. J. Cator (1936) did far-reaching research on the Chinese in Indonesia. Directed primarily at their economic role, his English-language study also looks at the historical development of the Chinese community during the nineteenth century and various other aspects such as the relevant law and sociological structure.

\section{Conclusion}

This essay has given a general review of doctoral research on the Netherlands-Indies accepted at the Faculty of Law of Leiden University from 1850 until 1940. It appears from this review that the emphasis of this research was on constitutional and administrative law subjects, with adat law coming in second place. In the twentieth century, theses on subjects related to commercial law, such as company or labor law become more frequent. The importance of Van Vollenhoven is underscored by the data which indicate that his prominence in promoting academic research is beyond question, yet, contrary to what one would expect, even during his tenure the emphasis was clearly on constitutional and administrative law, and not on adat.

This essay also has tried to give some impression of the framework within which these theses were completed, looking at the students, their post-doctorate careers, the university and the professors.

A proper assessment of the full value of this material is a matter for further research. This material is obviously a treasure trove which testifies of the richess and many-sidedness of research in the field of law in colonial times, and I hope further research on it will be carried out in Indonesia. 


\section{Doctoral Theses on the Netherlands-Indies Accepted at the Faculty of Law of Leiden University in the Period 1850-1940}

\section{C. de Waaij-Vosters}

1. ADAM, A.J.H.L.

Handhaving van bestaande verordeningen door de regeeringsreglementen van NederlandschIndië, Suriname en Curacao.

April 7, 1905

2. ADAM, L.

De autonomie van het Indonesische dorp.

October 10, 1924

3. ALTING VAN GEUSAU, W. H.

Neutraliteit der overheid in de Nederlandsche koloniën jegens godsdienstzaken.

October 19, 1917

4. ANGENENT, P. H.

De Vorstenlandsche waterschapsordonnantie toegelicht.

February 22, 1933

5. ASSEN, W. van.

De agrarische wet en de besluit tot hare uitvoering.

December 18, 1872

6. ATMADJA, $K$.

De mohammedaansche vrome stichtingen in Indië.

December 15, 1922

7. BAKKER, $P$.

Eenige beschouwingen over het geldverkeer in de inheemsche samenleving van NederlandschIndië.

March 20, 1936

8. BARLAGEN BUSSEMAKER, J.

lets over het landbezit van den inlander in Nederlandsch-Indië.

May 14, 1887

9. BECK, W. J.

Commentaar op de Indische onteigeningsverordening.

October 23, 1925

10. BEEKE, J.C.H. van der.

Het staatsblad.

April 23, 1915

11. BERCKEL, G.J.A. van.

Bijdrage tot de geschiedenis van het Europeesch opperbestuur over Nederlandsch-Indië van 1780-1806.

December 2, 1880

12. BLERKOM, M. van.

De ontwikkeling van de politierechtspraak in Nederlandsch-Indië.

January 21, 1916 
13. BLOM, P.A.F.

Kentrekken van het verwantschaps-, familie- en erfrecht bij de volken van Indonesië.

December 2, 1914

14. BOEKE, J. $\mathrm{H}$.

Tropisch-koloniale Staathuishoudkunde.

July 7, 1910

15. BOERENBEKER, E. A.

De vrouw in het Indonesisch adatrecht.

July 3,1931

16. BOEIJENGA, K. J.

Arbeidswetgeving in Nederlandsch-Indië.

December 17, 1926

17. BOOMGAARD, $\mathrm{S}$. R.

De rechtstoestand van de getrouwde vrouw volgens het adatrecht van Nederlandsch-Indië.

December 17, 1926

18. BORDEWIJK, H.W.C.

Rechtspersoonlijkheid der Nederlandsche koloniën.

December 22, 1905

19. BROKX, W.

Het recht tot wonen en tot reizen in Nederlandsch-Indië.

May 1, 1925

20. BROUWER, $M$.

Bestuursvormen en bestuursstelsels in de Minahassa.

October 16, 1936

21. BRUECKEL, A.J.W.

Indische bestuurshervorming; de tekst der wet.

December 17, 1930

22. BURGER, D. $\mathrm{H}$.

De ontsluiting van Java's binnenland voor het wereldverkeer.

April 25, 1939

23. CAMPEN, $\mathrm{H}$.

De regeling van het rechtswezen in de Buitengewesten.

July 7, 1939

24. CATOR, W. J.

The economic position of the Chinese in the Netherlands Indies.

June 22, 1936

25. CLERQ, P. H. le.

Vervolging in rechten van Inlandsche vorsten en Hoofden op Java: art. 84 Regeringsreglement van Nederlandsch-Indië.

1881

26. CORDES, J.W.C.

De privaatrechtelijke toestand der vreemde Oosterlingen op Java en Madoera.

September 30, 1887

27. COUPERUS, F. C.

Het rechtswezen op Sumatra's Westkust.

January 17,1882

28. DAM, W. P. van.

Inlandsche gemeente en Indonesisch dorp.

February 18, 1937 
29. DAVELAAR, W.A.J. van.

Het strafproces in zaken van misdrijf op de terechtzitting van de landsraden op Java en Madura, vergeleken met de Nederlandsche en Nederlandsch-Indische strafvordering. June 13,1884

30. DEINSE, H.K.J. van.

De toestand in de vorstenlanden.

December 19, 1887

31. DELDEN, C. H. van.

Bijdrage tot de arbeidswetgeving in Nederlandsch Oost-Indië.

July 8,1894

32. DELDEN, E. van.

De particuliere landerijen op Java.

May 10, 1911

33. DELDEN, H. R. van.

Over de erfelijkheid van de regenten op Java.

July 5,1862

34. DEVENTER, C. Th. van.

Zijn naar de grondwet onze koloniën deelen des rijks?

September 20, 1879

35. DIRKZWAGER, $\mathrm{N}$.

Eenige opmerkingen over den tweeden titel van het ontwerp Strafwetboek voor Europeanen in Nederlandsch-Indië.

July 7, 1892

36. DRIVERS, J.

De praktijk der conflictenregeling tusschen volksraad en regeering.

January 26, 1934

37. DUURVOORT, S. F.

Rechtspersonen in de Nederlandsche koloniën.

April 5, 1916

38. EISENBERGER, J.

Indië en de bedevaart naar Mekka.

November 30, 1928

39. ENDA, A. B.

Het grondenrecht in de Bataklanden : Tapanoeli, Simeloengen en het Karoland.

July 10,1925

40. ENGELBRECHT, W. A.

Artikel 2 Reglement op het beleid der Regering van Nederlandsch-Indië, in verband met art.

107 Reg. Reglement van Nederlandsch-Indië en de Nederlandsche wetgeving op het

Nederlanderschap.

January 14,1862

41. ENTHOVEN, K.L.J.

Het adatrecht der Inlanders in de jurisprudentie (1849-1912).

April 29, 1912

42. FRIS, G. W.

De toepasselijkheid van algemeene verordeningen op de zelfbestuursonderhoorigen in de buitengewesten.

April 26, 1940

43. GINKEL, H. Fievez Malines van

Overzicht van de Internationaal-rechtelijke betrekkingen van Nederlandsch-Indië (1850-1922).

November 13, 1924 
44. GOCKINGA, C. H.

Eene opmerking over art. 57 der Grondwet in verband met art. 44 van het Reglement op het beleid der Regeering van Nederlandsch-Indië. ?

45. GONDOKOESOEMO

Vernietiging van dorpsbesluiten in Indië.

June 29, 1922

46. GREUP, J.

De toepasselijkheid van de Grondwet op de Nederlandsche koloniën onderzocht.

December 18, 1906

47. GROBBEE, H. P.

De Panghoeloe als adviseur in strafzaken.

September 25, 1884

48. HAAR, Bzn., B. ter

Het adatproces der inlanders.

July 9,1915

49. HAGA, B. J.

Indonesische en Indische democratie.

December 10, 1924

50. HESLINGA, J. $\mathrm{H}$.

Het Inlandsch bestuur en zijn reorganisatie in Nederlandsch-Indië.

July 5, 1920

51. HEIJCOP TEN HAM, A.J.C.E. van

De berechting van civiele zaken en van misdrijven op de terechtzittingen der Landraden op Java en Madoera.

July 5,1888

52. HEIJMAN, A.

De Timor-tractaten (1859 en 1893).

May 17, 1895

53. HEIJTING, H. G.

De koelie-wetgeving voor de buitengewesten van Nederlandsch-Indië.

February 27, 1925

54. HOEK, J.H.J.

Het herstel van het Nederlandsch gezag over Java en de onderhoorigheden.

1862

55. HOVEN, $W$.

De Pasemah en haar verwantschaps-, huwelijks- en erfrecht.

December 19, 1927

56. HUENDER, $W$.

Overzicht van den economischen toestand der Inheemsche bevolking van Java en Madoera.

December 9, 1921

57. HUNGER, jr. F.W.T.

Federatieve staatsbouw. Een vraagstuk voor Nederlandsch-Indië.

December 14, 1928

58. JAARSMA, $S$.

Bewijsmiddelen van recht op grond in Nederlandsch-Indië.

November 7, 1918

59. JANSEN, A.

Vaststelling en verantwoording van de Indische begrooting 1814-1932.

July 8, 1932 
60. JAQUET, L.G.M.

De industrialisatie van Japan in verband met de Japansche handelsexpansie naar

Nederlandsch-Indië.

December 2, 1935

61. JOEKES, A. M.

Schets van de bevoegdheden der Nederlandsche consuls.

May 19, 1911

62. JONG, C.G.E. de

De organisatie der politie in Nederlandsch-Indië.

March 3, 1933

63. JONGMANS, P.H.C.

De exorbitante rechten van de Gouverneur-Generaal in de praktijk.

December 19, 1921

64. JONKER, J.Chr.G.

Over Javaansch strafrecht.

1882

65. JONKMAN, J. A.

Indonesisch nationale grondslag van het onderwijs ten dienste der Inlandsche bevolking.

July 11, 1918

66. JOUSTRA, W. G.

Indonesisch waterrecht.

December 12, 1922

67. JUYNBOLL, Th. W.

De hoofdregelen der Sjafi'itische leer van het pandrecht met een onderzoek naar haar ontstaan en naar haren invloed in Nederlandsch-Indië.

January 20, 1893

68. KITS VAN HEIJNINGEN, H. M. van

Het straf- en wraakrecht in den Indischen Archipel.

July 3,1916

69. KLEIN, J.J.W.

Bijdrage tot de studie van het intergentiel privaat- en vermogensrecht.

December 15, 1933

70. KLEIN, J. W. de

Het Preangerstelsel (1677-1871) en zijn nawerking.

December 11, 1931

71. KLEIJN, R. H. de

Het gewestelijk bestuur op Java.

January 18,1889

72. KOK, J. A.

De scheepvaartbescherming in Nederland en in Nederlandsch-Indië.

October 23, 1931

73. KORFF, K. H.

Koloniale concessiewetgeving.

May 9, 1913

74. KORN, V. E.

Het adatrecht van Bali.

November 18, 1924

75. KRONE, V.D.

Koning, Minister en Landvoogd.

June 29, 1922 
76. LEKKERKERKER, T. C.

Hindoerecht in Indonesië.

March 23, 1918

77. LENS, A.

De rechtstoestand in Nederlandsch-Indië van vereenigingen in Nederland als rechtspersonen erkend.

June 28, 1889

78. LESQUILLIER, N. W.

Het adatdelictenrecht in de magische wereldbeschouwing.

July 11, 1934

79. LETTE, J. R.

Proeve eener vergelijkende studie van het grondbezit in Rusland, zoals dit zich heeft ontwikkeld tot de Russische revolutie en op Java.

April 17, 1928

80. LEVYSSOHN NORMANN, H. D.

De Britsche heerschappij over Java en Onderhoorigheden.

October 31, 1857

81. LION CACHET, $C$.

Land en kerk in Nederlandsch-Indië. Historisch-staatsrechtelijke schets.

February 10, 1933

82. LOGEMANN, J.H.A.

De grondslagen der vennootschapsbelasting in Nederland en in Indië.

December 7, 1923

83. LOZE, T.H.M.

De Indische zelfbesturende landschappen in het nieuwe staatsbestel.

October 11, 1929

84. MACKAY, D. J.

De handhaaving van het Europeesch gezag en de hervorming van het regtswezen onder het bestuur van den Gouverneur-Generaal Mr. H.W. Daendels over Java en de Onderhoorigheden (1808-1811).

May 31, 1861

85. MALLINCKRODT, J.

Het adatrecht van Borneo.

July 12, 1928

86. MARCELLA, $\mathrm{H}$.

Algemeene bepalingen van wetgeving voor Nederlandsch-Indië.

May 30, 1913

87. MASSINK, $\mathrm{H}$.

Bijdrage tot de kennis van het vroeger en tegenwoordig bestuur op het eiland Madoera. April 30, 1888

88. MATTHES, H. J.

Eenige opmerkingen over de waarborgen waarmede de doodstraf in Nederlandsch Oost-Indië omgeven is.

June 18,1887

89. MEERTEN, H. C. van

Overzicht van de hervorming van het Preangerstelsel.

January 20, 1887

90. MEISS, J. $\mathrm{H}$.

Eenige bijdragen tot de kennis van den inwendigen toestand van Nederlandsch-Indië onder 
het bestuur van den Gouverneur-Generaal J.J. Rochussen (1841-1851).

December 21, 1883

91. MEIJENFELDT, H. D. von

De inheemsche rechtspraak in de zelfbesturende landschappen ter Oostkust van Sumatra.

November 20, 1936

92. MIEREMET, A.

De hedendaagsche inheemsche rechtspraak in Nederlandsch-Indië.

February 3, 1919

93. MOMMA, J. J.

Art. 56 van het Nederlandsch-Indisch Regeeringsreglement in zijne wording geschetst.

February 5, 1870

94. MUINCK, M. de

Onteigening in de Nederlandsche koloniën.

July 4, 1911

95. NEDERBURGH, C. B.

Bijdrage tot de interpretatie der artt. 78 al. 2 en 83 van het reglement van Nederlandsch-Indië in verband met art. 3 van het reglement op de Recht. Org. in Nederlandsch-Indië.

May 28, 1880

96. NEDERBURGH, I. A.

Het staatsdomein op Java.

October 7, 1882

97. NEEF, A. de

De regelingsbevoegdheid van de Kroon voor de koloniën.

July 9,1915

98. NIEUWENHUIJZEN, Th.

Sasaksch adatrecht.

November 28, 1932

99. OCKERS, B.

In- en overschrijving in Nederland en Nederlandsch-Indië.

February 10, 1928.

100. OPHUIJSEN, A. H. van

De huwelijksordonnantie en hare uitvoering.

December 13, 1907

101. OVERBEEK, W. H.

De rechtvaardigingsgronden in het Indisch strafrecht.

June 15, 1934

102. PANHUYS, F. G. van

Uitlevering van vreemde misdadigers m.b.t. onze Overzeesche bezittingen.

December 2, 1891

103. PEKELHARING, D. A.

De bevoegdhied van den Nederlandschen wetgever ten aanzien van de koloniën.

February 2, 1876

104. PENNINK, H. Ch.

Het reglement van 28 februari 1836 no 19 van de particuliere landerijen gelegen ten westen der rivier Tjimanoek op Java.

April 27, 1885

105. PIEREN, A.C.N.

De diensten aan de hoofden op Java en Madoera.

July 4,1884 
106. PIETERS, J. M.

De zoogenaamde ontvoogding van het inlandsch bestuur.

December 23, 1932

107. PLOEGSMA, N. D.

Oorspronkelijkheid en economisch aspect van het dorp op Java en Madoera.

December 11, 1936

108. PRANGE, A.J.A.

De Nederlandsch-Indische betalingsbalans.

July 8, 1935

109. PRONK, L.

De bestuursreorganisatie-Mullemeister op Java en Madoera en haar beteekenis voor het heden. June 3, 1929

110. REIJNST, J. C.

De afscheiding der rechterlijke en administratieve macht in Nederlandsch Oost-Indië.

April 13, 1878

111. REIJS, R.J.W.

De inkomstenbelasting der inlanders en met hen gelijkgestelden in Nederlandsch Oost-Indië.

December 17, 1925

112. RIDDER, J. de

De invloed van de westersche cultures op de autochtone bevolking ter oostkust van Sumatra. December 20, 1935

113. ROSKOTT, B. F.

De lagere Nederlandsch-Indische rechtsgemeenschappen en haar verhouding tot de centrale rechtsgemeenschap.

September 23, 1931

114. ROIJEN, J.W. van

De Palembangsche marga en haar grond- en waterrechten.

October 21, 1927

115. SAMKALDEN, I.

Het college van gedelegeerden uit den Volksraad.

March 11, 1938

116. SANDBERGEN, F.J.W.H.

Nederlandsche en Nederlandsch-Indische scheepsnationaliteit.

December 18, 1931

117. SANTHAGENS EIBERGEN, R. van

Vergelijking van het Nederlandsch-Indisch reglement op de strafvordering met het

Nederlandsch Wetboek van Strafvordering.

June 3, 1859

118. SCHILL, J.J.A.

Over de drukpers in Nederlandsch-Indië.

May 13, 1863

119. SCHRIEKE, J. J.

De ordonnantie met koninklijke medewerking.

April 2, 1909

120. SCHUESSLER, Chr.J.

Eenige opmerkingen naar aanleiding van art. 223 van het Inlandsch Reglement.

April 8, 1892

121. SEMLER, $H$.

De openbaarheid van den eigendom en der zakelijke regten, volgens het Burgerlijk Wetboek 
voor Nederlandsch-Indië, in vergelijking met het Nederlandsch Burgerlijk Wetboek.

March 24, 1860

122. SMIT, T.S.

Practijk der gewestelijke keuren in Nederlandsch-Indië, van 1922 tot en met 1926.

February 17, 1928

123. SOEBROTO

Indonesische Sawah-verpanding.

September 25, 1925

124. SOEKANTO, $R$.

Het gewas in Indonesië, religieus-adatrechtelijk beschouwd.

July 4, 1933

125. SOEPOMO

De reorganisatie van het agrarisch stelsel in het gewest Soerakarta.

July 8,1927

126. SOERIPTO

Ontwikkelingsgang der Vorstenlandsche wetboeken.

May 10, 1929

127. SPIT, H. J.

De Indische zelfbesturende landschappen. Hun mate van zelfstandigheid.

July 7, 1911

128. STOK, P.J.C. van der

Gouvernements-exploitatie in Nederlandsch-Indië.

July 1,1913

129. STOPPELAAR, J. W. de

Balambangansch adatrecht.

December 19, 1927

130. STRATEN, L. B.

De Indonesische bruidsschat.

January 19,1927

131. SOUMOKIL, C. R.

De deskundige in de Nederlandsch-Indische jurisprudentie. Studie van materieel strafrecht.

March 16, 1934

132. STURLER, J. E. de

Het grondgebied van Nederlandsch Oost-Indië in verband met de tractaten met Spanje, Engeland en Portugal.

June 24, 1881

133. TENDELOO, H.J.E.

Over de wenschelijkheid der invoering van het Torrenstelsel in Nederlandsch-Indië.

July 11, 1895

134. THOMAS, Th.

Eenige opmerkingen naar aanleiding van het pachtstelsel op Java.

March 3, 1893

135. TOBI, A. C.

De vrijwillige onderwerping aan het Europeesch privaatrecht.

January 7, 1927

136. TOEWATER, J. $\mathrm{H}$.

Over de rechterlijke inrichting in Nederlandsch Oost-Indië.

June 18, 1862

137. UEHLENBECK, G. W.

Bijdrage tot de geschiedenis van de verhouding tusschen den Staat en de Christelijke 
Kerkgenootschappen in Nederlandsch Oost-Indië.

December 20, 1887

138. VELDE, J. J. van de

De godsdienstige rechtspraak in Nederlandsch-Indië, staatsrechtelijk beschouwd.

October 9, 1928

139. VERSLUYS, J.D.N.

Vormen en soorten van loon in den Indische landbouw.

September 22, 1938

140. VISMAN, F. H.

Bevoegdheid der politie in Nederlandsch-Indië.

November 11, 1931

141. VISSER, J.H.W.B.

Eenige opmerkingen over eeden in den Nederlandsch-Indische archipel.

July 7, 1893

142. WAAL, H.L.E. de

De invloed der kolonisatie op het inlandsch recht in Nederlandsch Oost-Indië.

June 1,1880

143. WAAL, L. A. de

De finaciële zelfstandigheid van de locale zelfbesturen in Nederlandsch-Indië.

May 30, 1911

144. WAGENER, J. H.

De verhouding tusschen het Nederlandsche en het Nederlandsch-Indische privaatrecht. June 2, 1932

145. WILLINCK, G. D.

Het Nederlandsch-Indische muntwezen.

October 7, 1889

146. WOESTHOFF, P. F.

De locale verordeningen in het Nederlandsch-Indische staatsrecht.

April 26, 1904

147. WIJERS, G.

Het gezag in gewijsde in burgerlijke landraadzaken.

June 26, 1931

148. WIJTEMA, H. J.

Opperbestuur en algemeen bestuur over Nederlandsch-Indië, Suriname en Curacao. June 19, 1931

149. ZORAB, E.

De publiekrechtelijke toestand der vreemde Oosterlingen in Nederlandsch Oost-Indië.

December 8, 1890 